\title{
PENGARUH FDR TERHADAP ROA DENGAN VARIABEL INTERVENING NPF PADA BPRS INDONESIA 2011-2016
}

\author{
Arif Maulana \\ Departemen Ekonomi Syariah-Fakultas Ekonomi dan Bisnis-Universitas Airlangga \\ Email: arif-m-11@feb.unair.ac.id \\ Noven Suprayogi \\ Departemen Ekonomi Syariah-Fakultas Ekonomi dan Bisnis-Universitas Airlangga \\ Email: noven.suprayogi@feb.unair.ac.id
}

\begin{abstract}
:
This research aims to know the influence of Financing to Deposit Ratio (FDR) against Non-Performing Financing (NPF), the influence of Non-Performing Financing (NPF) towards profitability, leverage Financing to Deposit Ratio (FDR) towards profitability, on the Bank of the people's Islamic Financing in Indonesia. The approach used is the quantitative approach using path analysis. The sample used in this study is rural Islamic banks (BPRS) from the period of January 2011 to December 2016. The data is obtained from Islamic Banking Statistics released by Bank Indonesia (BI) and the Financial Services Authority (OJK) totaling 72 data. The results of this study showed that Non-Performing Financing (NPF) and the Financing to Deposit Ratio (FDR) have negative and significant influences on Profitability (ROA). Non-Performing Financing (NPF) has a positive influence on Profitability (RoA).
\end{abstract}

\section{Keywords: NPF, FDR, ROA, Intervening}

\section{PENDAHULUAN}

Indonesia memiliki 2 (dua) jenis bank yang beroperasi yaitu bank konvensional dan bank syariah. Menurut Wibowo (2013) terdapat perbedaan antara bank konvensional dengan bank syariah. Perbedaan tersebut terletak pada pembiayaan dan pemberian balas jasa yang diterima oleh bank dan investor. Balas jasa yang diberikan atau diterima pada bank konvensional berupa presentase yang sudah pasti. Jadi, bank konvensional tidak memperdulikan keadaan atau kondisi dari nasabah peminjam dana, apakah nasabah tersebut masih mampu dalam melunasi pinjamannya ataupun tidak. Sedangkan, pada bank syariah akan memberi dan menerima balas jasa dengan berdasarkan akad yang telah disepakati sebelumnya.
Bank syariah akan memperoleh bagi hasil dari proyek yang telah dibiayai oleh bank syariah. Dan apabila proyek tersebut gagal, maka bank syariah akan mencarikan solusi penyelesaian. Bank konvensional lebih sering mendapatkan profitabilitas yang tinggi dibandingkan dengan bank syariah, namun terkadang bank syariah bisa mendapatkan profitabilitas yang lebih tinggi dibandingkan dengan profitabilitas yang didapat oleh bank konvensional.

Bank Perkreditan Rakyat (BPR) merupakan salah satu perbankan yang telah menerapkan sistem ekonomi syariah. Namun, menurut Peraturan Perundangundangan No. 21 Tahun 2008 ayat 8, Bank Perkreditan Rakyat (BPR) telah berganti menjadi Bank Pembiayaan Rakyat Syariah (BPRS). Berdasarkan Undang-Undang No.

1) Jurnal ini merupakan bagian dari skripsl Arif Maulana, NIM: 041114065, yang diuji pada tanggal 18 Juli 2018. 
7 Tahun 1992 tentang Perbankan dan Peraturan Pemerintah (PP) No. 72 Tahun 1992 Bank Pembiayaan Rakyat Syariah (BPRS) merupakan Bank dengan menggunakan Prinsip Bagi Hasil. Bank Pembiayaan Rakyat Syariah (BPRS) berada dibawah naungan Departemen Koperasi dan Usaha Kecil dan Menengah. Bank Pembiayaan Rakyat Syariah (BPRS) lebih bersifat prosedural. Dimana, modal yang didapat Bank Pembiayaan Rakyat Syariah (BPRS) biasanya berasal dari pemegang saham, para pendukung kerja yang telah layak dan memenuhi standarisasi dari Bank Pembiayaan Rakyat Syariah (BPRS).Bank Pembiayaan Rakyat Syariah didirikan sebagai langkah aktif dalam restrukturisasi perekonomian lebih banyak terjadi penunggakan pembayaran kredit oleh debitur, maka bank tidak dapat mengembalikan modal yang telah dikeluarkan. Sehingga hal ini akan mengakibatkan pembiayaan macet dan dapat mempengaruhi profitabilitas pada BPRS.

Bank Pembiayaan Rakyat Syariah didirikan sebagai langkah aktif dalam restrukturisasi perekonomian Indonesia yang dituangkan dalam berbagai paket kebijaksanaan keuangan, moneter, dan perbankan secara umum, dan secara khusus mengisi peluang terhadap kebijaksanaan Bank Konvensional dalam penetapan tingkat suku bunga (rate of interest). Selanjutnya BPR Syariah secara luas dikenal sebagai sistem perbankan bagi hasil atau sistem perbankan Islam. Dan diharapkan dengan adanya BPR
Syariah dapat membuat kemakmuran ekonomi yang meluas, tingkat kerja penuh dan tingkat pertumbuhan ekonomi yang optimum, keadilan sosial- ekonomi dan distribusi pendapatan serta kekayaan yang merata, stabilitas nilai vang, mobilisasi dan investasi tabungan yang menjamin adanya pengembalian yang adil dan pelayanan yang efektif.

$$
\text { Profitabilitas pada Bank }
$$

Pembiayaan Rakyat Syariahyang ditunjukkan melalui rasio ROA selama tahun 2011-2016 mengalami fluktuasi. Rasio profitabilitas pada tahun 2014 hingga 2016 mengalami penurunan dibanding tahun sebelumnya. Rasio tahun 2014 sebesar 2,26\%. Sedangkan pada tahun 2015 cenderung menurun lagi menjadi 2,20\%. Pada tahun 2016 sebesar $2,27 \%$. Fluktuasi ROA yang terjadi selama enam tahun pengamatan dipengaruhi oleh banyak hal seperti FDR dan risiko pembiayaan.

Bank Pembiayaan Rakyat Syariah juga akan mengalami ancaman risiko seperti perbankan syariah. Menurut Sari (2012), risiko yang sering dihadapi oleh perbankan syariah secara umum dapat diklasifikasikan menjadi dua kategori, yaitu risiko yang lazim dihadapi oleh bank konvensional sebagai lembaga intermediasi keuangan dan risiko yang melekat pada bank sebagai konsekuensi kepatuhan terhadap prinsip-prinsip syariah. Risiko pembiayaan dalam hal ini diproksikan dengan Non Performing Financing (NPF) adalah salah satu risiko yang akan dihadapi oleh perbankan 
syariah termasuk bank pembiayaan rakyat syariah. Risiko pembiayaan bisa saja mengalami penurunan eksistensi dari Bank Pembiayaan Rakyat Syariah apabila tidak langsung ditangani.

Selama enam tahun terakhir, dari data statistik bank pembiayaan rakyat syariah yang dirilis oleh Bank Indonesia tercatat jika risiko pembiayaan selalu mengalami peningkatan yang cukup signifikan diantaranya pada tahun 2014 risiko pembiayaan telah tercatat sebesar $7,89 \%$ dan di tahun 2015 risiko pembiayaan mengalami peningkatan menjadi sebesar 8,20\%. Kemudian risiko pembiayaan meningkat menjadi 8,63\% di tahun 2016 . Jadi, kenaikan risiko pembiayaan ini sangat mengkhawatirkan karena Bank Indonesia menetapkan standar risiko pembiayaan bermasalah sebesar $5 \%$.

Apabila lebih banyak terjadi penunggakan pembayaran kredit oleh debitur, maka bank tidak dapat mengembalikan modal yang telah dikeluarkan. Sehingga hal ini akan mengakibatkan pembiayaan macet dan dapat mempengaruhi profitabilitas pada BPRS.

\section{Rumusan Masalah}

1. Apakah Financing to Deposit Ratio (FDR) berpengaruh terhadap Non Performing Financing (NPF) BPR Syariah di Indonesia?

2. Apakah Non Performing Financing (NPF) berpengaruh terhadap profitabilitas BPR Syariah di Indonesia?
3. Apakah Financing to Deposit Ratio (FDR) berpengaruh terhadap profitabilitas BPR Syariah di Indonesia

\section{Tujuan Penelitian}

1. Menganalisis pengaruh Financing to Deposit Ratio (FDR) terhadap Non Performing Financing (NPF)

2. Menganalisis pengaruh Non Performing Financing (NPF) terhadap profitabilitas.

3. Menganalisis pengaruh Financing to Deposit Ratio (FDR) terhadap profitabilitas.

II. LANDASAN TEORI DAN PENGEMBANGAN HIPOTESIS

Bank Pembiayaan Rakyat Syariah adalah salah satu lembaga kevangan perbankan syariah yang pola operasionalnya mengikuti prinsip prinsip syariah dengan berpedoman pada AlQuran dan Al-hadist. BPRS berdiri berdasarkan Undang Undang No.7 tahun 1992 tentang perbankan dan Peraturan Pemerintah (PP) No.72 tahun 1992 tentang Bank. Pada pasal 1 Undang Undang No.10 tahun 1998 disebutkan bahwa BPRS adalah Bank yang melaksanakan kegiatan usaha berdasarkan prinsip syariah yang kegiatannya tidak memberikan jasa dalam lalu lintas pembayaran. Secara teknis, BPRS bisa diartikan lembaga keuangan sebagaimana BPR konvensional yang pengoperasiannya menggunkan prinsip prinsip syariah terutama dalam pemberian bagi hasil. 


\section{Kinerja Kevangan Bank Pembiayaan Syariah}

Suatu pengukuran tingkat
kesehatan BPR Syariah dalam
kemampuan kerja dan produktifitasnya
adalah dengan menilai tingkat kinerja
atau keragaan dari lembaga yang
bersangkutan.

1. Return on Assets

Rasio ini digunakan untuk mengukur kemampuan manajemen bank dalam memperoleh keuntungan (laba) secara keseluruhan.

2. Non Performing Financing

NPF merupakan rasio yang menunjukkan kemampuan manajemen bank dalam mengelola penbiayaan bermasalah yang diberikan oleh bank. Sehingga semakin tinggi rasio ini maka akan semakin semakin buruk kualitas pembiayaan bank yang menyebabkan jumlah pembiayaan bermasalah semakin besar, maka kemungkinan suatu bank dalam kondisi bermasalah semakin besar. Pembiayaan dalam hal ini adalah pembiayaan yang diberikan kepada pihak ketiga tidak termasuk pembiayaan kepada bank lain. Pembiayaan bermasalah adalah pembiayaan dengan kualitas kurang lancar, diragukan, dan macet.

3. Financing to Deposit Ratio

FDR adalah rasio antara seluruh jumlah pembiayaan yang diberikan bank dengan dana yang diterima oleh bank. Financing to Deposit Ratio menyatakan seberapa jauh kemampuan bank dalam membayar kembali penarikan dana yang dilakukan deposan dengan mengandalkan pembiayaan yang diberikan sebagai sumber likuiditasnya. Semakin tinggi rasio FDR, semakin rendah kemampuan likuiditas suatu bank. Batas aman FDR suatu bank adalah di bawah 110 persen.

Bank Indonesia memberikan pembatasan jumlah pembiayaan yang disalurkan secara keseluruhan melalui penetapan rasio atau perbandingan antara jumlah pembiayaan yang diberikan terhadap jumlah simpanan dana pihak ketiga (masyarakat) yang berhasil dihimpun oleh bank yang bersangkutan. Ini berarti jumlah pembiayaan terhadap dana pihak ketiga tidak boleh melebihi ketentuan. Menurut ketentuan Bank Indonesia, maka rasio yang paling sehat adalah paling tinggi 94,75 persen.

Hal tersebut berarti dana yang terhimpun, secara optimal dapat disalurkan ke pembiayaan yang merupakan aset yang paling produktif bagi bank. Tentunya apabila pembiayaan tersebut berjalan dengan baik. Di pihak lain, bank masih mempunyai alat likuid yang memadai untuk mengantisipasi penarikan dari para penyimpan dana. 


\section{Hubungan Antar Variabel}

1. Pengaruh FDR terhadap NPF Pembiayaan bermasalah atau disebut juga Non Performing Financing (NPF) muncul akibat dari ketidak mampuan nasabah untuk melunasi pinjaman pada waktu yang telah ditentukan. Menurut pendapat Muhammad (2004.359), pembiayaan bermasalah muncul manakala bank tidak dapat memperoleh kembali tagihannya atas pinjaman yang diberikan dari investasi yang sedang dilakukannya. Penyebab utama dari peristiwa ini adalah penilaian pembiayaan yang kurang cermat dan lemahnya antisipasi terhadap berbagai kemungkinan usaha yang dibiayainya. Hubungan pembiayaan terhadap Non Performing Financing (NPF) telah dilakukan penelitian sebelumnya oleh Afif (2014) tentang "Pengaruh Pembiayaan terhadap Laba melalui Variabel Intervening Pembiayaan Bermasalah Bank Umum Syariah di Indonesia Periode 20092013". Hasil dari penelitian tersebut menjelaskan bahwa pembiayaan memiliki pengaruh positif terhadap pembiayaan bermasalah Bank Umum Syariah.

Hal ini menunjukkan bahwa semakin tinggi bank syariah menyalurkan pembiayaan, maka akan mengakibatkan terjadinya pembiayaan bermasalah atau resiko pembiayaan. Oleh karena itu bank sebagai pemberi dana harus meminimalkan tingkat Non Performing Financing (NPF). Penyaluran pembiayaan tentunya terkait dengan Financing to Deposit Rasio (FDR), sebab untuk mengetahui berapa besar pembiayaan yang disalurkan dengan memanfaatkan dana yang dihimpun dapat menggunakan rasio FDR. Bank yang mempunyai NPF tinggi mengindikasikan bahwa tingkat risiko atas penyaluran pembiayaan pada bank tersebut cukup tinggi pula.

2. Pengaruh NPF terhadap ROA Penanaman dana bank syariah pada aktiva produktif wajib dilaksanakan berdasarkan prinsip kehati-hatian (Muhammad, 2004;120). Selain itu Muhammad (2004:117) menambahkan, bahwa kualitas penanaman dana yang baik akan menghasilkan keuntungan. Penanaman dana yang dimaksudkan salah satunya adalah dalam bentuk pembiayaan yang diberikan kepada nasabah.

Muhammad

(2004:127) menjelaskan bahwa kegiatan penanaman dana dapat menimbulkan risiko kerugian. Risiko kerugian ini dapat berasal dari adanya pembiayaan bermasalah yang dihadapi bank. Non Performing Financing (NPF) merupakan rasio yang digunakan untuk mengetahui berapa besar pembiayaan yang dihadapi bank. Purbaningsih (2014) menyatakan NPF yang semakin besar akan menyebabkan pendapatan yang 
diterima bank semakin berkurang, sehingga apabila pendapatan yang diterima semakin berkurang maka akan menurunkan profitabilitas (ROA). Peningkatan NPF menyebabkan ROA menurun.

Hasil penelitian yang dilakukan Pratiwi (2012) menyatakan bahwa NPF berpengaruh negatif dan signifikan terhadap ROA.

3. Pengaruh FDR terhadap ROA

Salah satu fungsi perusahaan perbankan sebagai lembaga intermediasi adalah menyalurkan pembiayaan kepada nasabah/masyarakat yang membutuhkan dana tambahan untuk melakukan ekspansi usaha. Untuk mengetahui berapa besar pembiayaan yang disalurkan dengan memanfaatkan dana yang dihimpun dapat menggunakan rasio FDR. Hal ini sesuai dengan hasil penelitian yang dilakukan Nur Abidah Mukti (2016) yang dalam penelitiannya menyatakan bahwa Financing to Deposit Ratio (FDR) berpengaruh positif signifikan terhadap Profitabilitas (ROA), yang artinya kenaikan FDR akan diikuti oleh kenaikan ROA.

Hasil penelitian yang dilakukan oleh Sabir, dkk (2012) menyatakan bahwa FDR pada Bank Umum Syariah berpengaruh positif dan signifikan terhadap ROA.

\section{METODE PENELITIAN}

\section{Jenis Penelitian}

Penelitian ini merupakan penelitian empiris dalam bentuk pengujian hipotesis dengan metode kausalitas yaitu dengan mengukur pengaruh dan keterkaitan antara variabel yang satu dengan variabel yang lainnya. Variabel-variabel dalam penelitian ini terdiri dari FDR, NPF dan Profitabilitas yang telah dirumuskan menjadi beberapa hipotesis yang siap untuk diuji.

\section{Jenis dan Sumber Data}

Jenis data yang digunakan dalam penelitian ini adalah kuantitatif. Sumber data yang digunakan dalam penelitian ini adalah data sekunder. Data sekunder merupakan sumber data penelitian yang diperoleh peneliti secara tidak langsung melalui media perantara (Indriantoro dan Supomo, 2013:147). Data sekunder yang digunakan berupa Laporan Keuangan Tahunan pada BPRS di Indonesia yang diterbitkan oleh Otoritas Jasa Keuangan dalam website resmi Bank Indonesia. Adapun periodesasi data yang diambil dalam penelitian ini adalah selama enam tahun, yaitu tahun 2011-2016.

\section{Teknik Pengumpulan Data}

Dalam melaksanakan penelitian ini, pengumpulan data yang dilakukan melalui metode dokumentasi yaitu proses pengumpulan data yang digunakan untuk penelitian yang diperoleh dari laporan keuangan yang dipublikasikan oleh OJK. 


\section{Populasi dan Sampel}

Populasi dalam penelitian ini adalah Bank Pembiayaan Rakyat Syariah yang terdaftar di Bank Indonesia mulai tahun 2011-2016. Sampel penelitian diambil secara sampling jenuh, yaitu semua anggota populasi digunakan sebagai sampel.

\section{Definisi Operasional Variabel}

Variabel yang digunakan dalam penelitian ini terdiri dari tiga jenis variabel, yaitu: Variabel Laten Eksogen $(X)$ dan variabel laten endogen ( $Y$ \& $Z$ ). Yang menjadi variabel laten eksogen dalam penelitian ini adalah Financing to Deposit Ratio (FDR). Sedangkan yang menjadi variabel laten endogen dalam penelitian ini adalah Risiko Pembiayaan (NPF) dan Profitabilitas (ROA).

Selanjutnya Financing to Deposit Ratio (FDR) adalah rasio antara seluruh jumlah pembiayaan yang diberikan bank dengan dana yang diterima bank. FDR dapat dirumuskan sebagai berikut (Statistik Perbankan Syariah Januari 2016) : FDR $=\frac{\text { total pembiayaan }}{\text { dana yang diterima bank }} \times 100 \%$

Non Performing Financing (NPF) digunakan untuk mengukur risiko pembiayaan. NPF merupakan perbandingan antara pembiayaan bermasalah dengan total pembiayaan. NPF dapat dirumuskan sebagai berikut (Statistik Perbankan Syariah Januari 2016) : $\mathrm{NPF}=\frac{\text { total pembiayaan bermasalah }}{\text { total pembiayaan }} \times 100 \%$

Profitabilitas merupakan laba (sebelum pajak) dengan total aset yang dimiliki bank pada periode tertentu. Profitabilitas dapat dirumuskan sebagai berikut (Statistik Perbankan Syariah Januari 2016): ROA $=\frac{\text { laba setelah pajak }}{\text { total asset }} \times 100 \%$

Menurut Indriantoro (2013c:170), statistik deskriptif digunakan untuk memberikan informasi mengenai karakteristik dari variabel penelitian. Dalam penelitian ini, statistik deskriptif digunakan untuk menginterpretasikan variabel FDR, Risiko NPF dan Profitabilitas dengan menggunakan tabel distribusi frekuensi yang menunjukkan nilai minimum, nilai maksimum, rata-rata, median dan standar deviasi.

\section{HASIL DAN PEMBAHASAN}

\section{Gambaran Obyek Penelitian}

Sampel penelitian ini diambil secara sampling jenuh. Penelitian ini dilakukan pada tahun 2011-2016 dengan sampel seluruh BPRS di Indonesia.

\section{Statistik Deskriptif}

Menurut Indriantoro (2013c:170), statistik deskriptif digunakan untuk memberikan informasi mengenai karakteristik dari variabel penelitian dengan menggunakan tabel distribusi frekuensi yang menunjukkan nilai minimum, nilai maksimum, rata-rata, median dan standar deviasi. Variabel yang digunakan dalam penelitian ini adalah, FDR (X), Risiko Pembiayaan (Z), dan Profitabilitas (Y). Berikut ini merupakan tabel statistik deskriptif : 
Tabel 1. Statistik Deskriptif

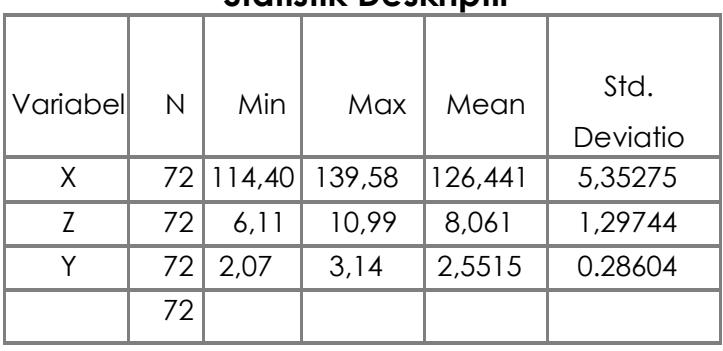

Berdasarkan tabel 1 diatas, Untuk variabel Financing to Deposit Ratio jumlah data 72 , nilai minimum 114,40, nilai maksimum 139,58, rata-rata 126,4411, dan standar deviasi 5,35275. Untuk variabel Non Performing Financing jumlah data 72 , nilai minimum 6,11, nilai maksimum 10,99, ratarata 8,0610, dan standar deviasi 1,29744. Dan untuk variabel Return on Assets jumlah data 72 , nilai minimum 2,07 , nilai maksimum 3,14, rata-rata 2,5515, dan standar deviasi 0,28604.

\section{Uji Asumsi Klasik}

Setelah dilakukan uji asumsi klasik yang meliputi uji normalitas, uji multikolinearitas, uji heteroskedastisitas, dan uji autokorelasi disimpulkan bahwa data dalam penelitian ini bisa dikatakan baik dan tidak terdapat masalah pada uji asumsi klasik.

\section{Analisis Jalur (Path Analysis)}

Tabel 2.

Hasil Analisis FDR (X) terhadap NPF (Z) Coefficients ${ }^{a}$

\begin{tabular}{|l|l|l|l|l|l|}
\hline Variabel & B & $\begin{array}{l}\text { Std. } \\
\text { Error }\end{array}$ & Beta & ${ }^{\dagger}$ & Sig \\
\hline $\begin{array}{l}\text { (Const } \\
\text { ant) }\end{array}$ & 15.141 & 3.567 & & 4.244 & .000 \\
\hline
\end{tabular}

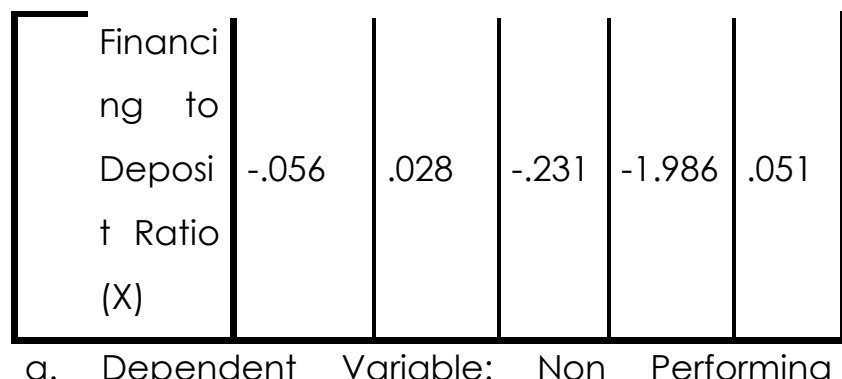

a. Dependent Variable: Non Performing Financing (Z)

sumber: Lampiran 8

Hasil Persamaan regresi sebagai berikut:

$Z=15,141+(-0,056) X$

Arti angka-angka tersebut sbb: (yang akan dijelaskan disini adalah variabel independen yang berpengaruh terhadap variabel dependen)

Konstanta sebesar 15,141; artinya jika FDR (X) nilainya adalah 0 , maka besarnya NPF

(Z) nilainya sebesar 15,141.

Tabel 3.

Hasil Analisis Financing to Deposit Ratio $(X)$, Non Performing Financing ( $Z$ ) Terhadap Return On Assets ( $Y$ )

Coefficientsa

\begin{tabular}{|l|l|l|l|l|l|}
\hline Variabel & B & $\begin{array}{l}\text { Std. } \\
\text { Error }\end{array}$ & Beta & S & Sig \\
\hline lConstant & 4.84 & .588 & & 8.245 & .000 \\
Financing & 9 & & & & \\
to & & & & & \\
Deposit & -.007 & .004 & -.134 & -1.677 & .098 \\
Ratio (X) & & & & & \\
Non & & & & & \\
Performin & & & & & \\
Financing & & & & & \\
(Z) & & & & & \\
\hline
\end{tabular}

a. Dependent Variable: Return on Assets (Y)

sumber: Lampiran 15

Persamaan regresi sebagai berikut:

$Y=4,849+(-0,007) X+(-0,173) Z$ 
Arti angka-angka tersebut sebagai berikut: (yang akan dijelaskan disini adalah variabel independen yang berpengaruh terhadap variabel dependen)

-Konstanta sebesar 4,849; artinya jika Financing to Deposit Ratio dan Non Performing Financing nilainya adalah 0 , maka besarnya nilai Return on Assets ( $Y$ ) nilainya sebesar 4,849.

- Koefisien regresi variabel Non Performing Financing (Z) sebesar -0,173; artinya setiap peningkatan Non Performing Financing sebesar 1 satuan, maka akan meningkatkan Return on Assets sebesar 0,173 satuan, dengan asumsi variabel independen lain nilainya tetap.

Berdasarkan tabel diatas, maka persamaan dalam penelitian ini yang terbentuk adalah sebagai berikut

$$
\begin{aligned}
Z & =\rho x z \cdot X+\varepsilon 1 \\
& =-0,231 X \\
Y & =\rho x y \cdot X+\rho z y \cdot Z+\varepsilon 2 \\
& =-0,134 X+(-0,785) Z
\end{aligned}
$$

Uji $\dagger$

Oleh karena nilai $-\dagger$ hitung $\geq-\dagger$ tabel $(-1,986 \geq-$ 1,994), maka Ho diterima, artinya bahwa Financing to Deposit Ratio (X) tidak berpengaruh terhadap Non Performing Financing (Z) BPR Syariah di Indonesia.

Oleh karena nilai - $\dagger_{\text {hitung }}<-\dagger$ tabel $(-9,844<-$ 1,995), maka Ho ditolak, artinya bahwa Non Performing Financing berpengaruh terhadap Return on Assets BPR Syariah di Indonesia. Nilai † hitung negatif, artinya berpengaruh negatif yaitu semakin meningkat Non Performing Financing maka akan menurunkan Return on Assets.
Oleh karena nilai $-\dagger$ hitung $\geq-\dagger$ tabel $(-1,677 \geq-$ 1,995), maka Ho diterima, artinya bahwa Financing to Deposit Ratio tidak berpengaruh terhadap Return on Assets BPR Syariah di Indonesia.

\section{Uji Koefisien Determinasi ( $\left.\mathbf{R}^{\mathbf{2}}\right)$}

Hasil analisis determinasi $\left(R^{2}\right)$ yang diperoleh setelah data diolah disajikan dalam tabel berikut ini:

\section{Tabel 4.}

Hasil Analisis Koefisien Determinasi Financing to Deposit Ratio (X), Non Performing Financing ( $Z$ ) Terhadap Return On Assets ( $Y$ )

\section{Model Summary ${ }^{b}$}

\begin{tabular}{|l|l|l|l|}
\hline Model & $R$ & R Square & Adjusted R Square \\
\hline 1 & $.765 a$ & .585 & .573 \\
\hline
\end{tabular}

a. Predictors: (Constant), Non Performing Financing (Z), Financing to Deposit Ratio (X) b. Dependent Variable: Return on Assets $(Y)$ Sumber: Lampiran 15

Berdasarkan tabel di atas diketahui nilai $\mathrm{R}^{2}$ sebesar 0,585 (58,5\%). Hal ini menunjukkan bahwa variasi variabel independen dan mediasi yang digunakan dalam model (Financing to Deposit Ratio dan Non Performing Financingl mampu menjelaskan sebesar 58,5\% variasi variabel Return on Assets, dan sisanya dijelaskan oleh variabel lain yang tidak dimasukkan dalam model penelitian ini. Koefisien Korelasi® sebesar 0,765 menunjukkan bahwa hubungan variabel Financing to DepositRatio (X) dan Non Performing Financing (Z) terhadap Return on Assets (RoA) cukup kuat. 


\section{Pembahasan}

Pengaruh Financing to Depost Ratio (X) Terhadap Non Performing Financing (Z)

Hasil pengujian hipotesis pertama menunjukkan bahwa Financing to Deposit Ratio (FDR) tidak mempunyai pengaruh terhadap Non Performing Financing (NPF). Hal ini dikarenakan nilai $-\dagger$ hitung $\geq-\dagger$ tabel ($1,986 \geq-1,994$ ) dengan signifikansi 0,051, maka Ho diterima, artinya bahwa Financing to Deposit Ratio (X) tidak berpengaruh terhadap Non Performing Financing (Z) BPR Syariah di Indonesia. Hasil uji tersebut ternyata tidak sesuai dengan kondisi BPR Syariah di Indonesia yang ditunjukkan melalui hasil kinerja kevangannya, yaitu selama periode 2011 sampai 2016 rasio NPF dan FDR mengalami kenaikan. Menurut pendapat Muhammad (2004.359), pembiayaan bermasalah muncul manakala bank tidak dapat memperoleh kembali tagihannya atas pinjaman yang diberikan dari investasi yang sedang dilakukannya. Hubungan pembiayaan terhadap Non Performing Financing (NPF) telah dilakukan penelitian sebelumnya oleh Afif (2014) tentang "Pengaruh Pembiayaan terhadap Laba melalui Variabel Intervening Pembiayaan Bermasalah Bank Umum Syariah di Indonesia Periode 20092013". Hasil dari penelitian tersebut menjelaskan bahwa pembiayaan memiliki pengaruh positif terhadap pembiayaan bermasalah Bank Umum Syariah. Hal ini menunjukkan bahwa semakin tinggi bank syariah menyalurkan pembiayaan, maka akan mengakibatkan terjadinya pembiayaan bermasalah atau resiko pembiayaan. Oleh karena itu bank sebagai pemberi dana harus meminimalkan tingkat Non Performing Financing (NPF). Penyaluran pembiayaan tentunya terkait dengan Financing to Deposit Rasio (FDR), sebab untuk mengetahui berapa besar pembiayaan yang disalurkan dengan memanfaatkan dana yang dihimpun dapat menggunakan rasio FDR. Bank yang mempunyai NPF tinggi mengindikasikan bahwa tingkat risiko atas penyaluran pembiayaan pada bank tersebut cukup tinggi

\section{Pengaruh Financing Financing to Deposit Ratio (X) terhadap Return on Assets ( $Y$ )}

Hasil pengujian hipotesis kedua menunjukkan bahwa Financing to Deposit Ratio (FDR) tidak mempunyai pengaruh terhadap Return on Assets (RoA). Hal ini dikarenakan nilai - $\dagger$ hitung $\geq-\dagger$ tabel $(-1,677 \geq$ $1,995)$ dengan nilai signifikansi 0,098 , maka Ho diterima, artinya bahwa Financing to Deposit Ratio (X) tidak berpengaruh terhadap Return on Assets (Y) BPR Syariah di Indonesia. Untuk mengetahui berapa besar pembiayaan yang disalurkan dengan memanfaatkan dana yang dihimpun dapat menggunakan rasio FDR. Dalam bank konvensional FDR lebih dikenal dengan sebutan LDR. Sukarno dan Syaichu (2006) menjelaskan bahwa semakin tinggi LDR laba perusahaan mempunyai kemungkinan untuk meningkat dengan catatan bahwa bank tersebut mampu menyalurkan kreditnya secara optimal, maka disimpulkan LDR 
berpengaruh positif terhadap laba. Sama halnya pada FDR, apabila FDR naik maka laba yang diperoleh bank juga naik dengan asumsi bahwa bank mampu menyalurkan pembiayaan secara optimal. Peningkatan pada FDR menyebabkan peningkatan pada profitabilitas (ROA). Hasil penelitian yang dilakukan oleh Sabir, dkk (2012) menyatakan bahwa FDR pada Bank Umum Syariah berpengaruh positif dan signifikan terhadap RoA. Hasil uji tersebut ternyata tidak sesuai dengan kondisi BPR Syariah di Indonesia yang ditunjukkan melalui hasil kinerja keuangannya selama periode 2011 sampai 2016 yaitu rasio FDR mengalami kenaikan dan disisi lain rasio RoA mengalami penurunan, artinya kenaikan FDR tidak diikuti dengan kenaikan RoA.

Pengaruh Non Performance Financing (Z) terhadap Return on Assets ( $Y$ )

Hasil pengujian hipotesis ketiga menunjukkan bahwa Non Performance Financing (NPF) mempunyai pengaruh terhadap Return on Assets (RoA). Hal ini dikarenakan nilai - $\dagger$ hitung $<-\dagger$ tabel $(-9,844<-$ 1,995) dengan signifikansi 0,000 , maka Ho ditolak, artinya bahwa Non Performing Financing $(X)$ berpengaruh terhadap Return on Assets (Y) BPR Syariah di Indonesia. Hasil uji tersebut ternyata tidak sesuai dengan kondisi BPR Syariah di Indonesia yang ditunjukkan melalui hasil kinerja keuangannya, yaitu selama periode 2011 sampai 2016 rasio NPF mengalami kenaikan dan disisi lain rasio RoA mengalami penurunan.
Penanaman dana bank syariah pada aktiva produktif wajib dilaksanakan berdasarkan prinsip kehati-hatian (Muhammad, 2004;120). Selain itu Muhammad (2004:117) menambahkan, bahwa kualitas penanaman dana yang baik akan menghasilkan keuntungan. Penanaman dana yang dimaksudkan salah satunya adalah dalam bentuk pembiayaan yang diberikan kepada nasabah. Muhammad (2004:127) menjelaskan bahwa kegiatan penanaman dana dapat menimbulkan risiko kerugian. Risiko kerugian ini dapat berasal dari adanya pembiayaan bermasalah yang dihadapi bank. Non Performing Financing (NPF) merupakan rasio yang digunakan untuk mengetahui berapa besar pembiayaan yang dihadapi bank. Purbaningsih (2014) menyatakan NPF yang semakin besar akan menyebabkan pendapatan yang diterima bank semakin berkurang, sehingga apabila pendapatan yang diterima semakin berkurang maka akan menurunkan profitabilitas (ROA). Peningkatan NPF menyebabkan RoA menurun. Hasil uji tersebut ternyata sesuai dengan kondisi BPR Syariah di Indonesia yang ditunjukkan melalui hasil kinerja kevangannya selama periode 2011 sampai 2016 yaitu rasio NPF mengalami kenaikan dan disisi lain rasio RoA mengalami penurunan, artinya kenaikan NPF diikuti dengan penurunan RoA.

\section{SIMPULAN}

Berdasarkan hasil uji analisis jalur dan uji hipotesis dapat diambil kesimpulan 
bahwa Financing to Deposit Ratio tidak berpengaruh terhadap Non Performing Financing BPR Syariah di Indonesia. Hal ini ditunjukkan oleh uji $\dagger$ yang didapat nilai - $\dagger$ hitung $\geq-\dagger$ tabel $(-1,986 \geq-1,994)$, maka Ho diterima.

Financing to Deposit Ratio secara parsial tidak berpengaruh terhadap Return on Assets BPR Syariah di Indonesia. Hal ini ditunjukkan oleh uji $†$ yang didapat nilai - $\dagger$ hitung $\geq-\dagger$ tabel $(-1,677 \geq-1,995)$, maka Ho diterima.

Non Performing Financing secara parsial berpengaruh terhadap Return on Assets BPR Syariah di Indonesia. Hal ini ditunjukkan oleh uji † yang didapat nilai - † hitung $<-\dagger$ tabel $(-9,844<-1,995)$, maka Ho ditolak. Nilai $\dagger$ hitung negatif, artinya berpengaruh negatif yaitu semakin meningkat Non Performing Financing maka akan menurunkan Return on Assets.

Variabel Non Performing Financing memediasi hubungan antara Financing to Deposit Ratio dengan Return on Assets. Hal ini dapat dilihat dari besarnya koefisien pengaruh langsung FDR ke RoA lebih kecil dari pengaruh tidak langsung FDR ke RoA melalui NPF.

\section{DAFTAR PUSTAKA}

Afif, Z. N. (2014). Pengaruh Pembiayaan Murabahah Terhadap Laba Melalui Variabel Intervening Pembiayaan Bermasalah Bank Umum Syariah di Indonesia Periode 2009-2013. (Skripsi S1), Fakultas Ekonomi dan Bisnis Universitas Airlangga
Indriantoro, Nur., dan Supomo, Bambang. (2013). Metodologi Penelitian Bisnis Untuk Akuntansi \& Manajemen. Yogyakarta: BPFE

Muhammad. (2004). Manajemen Dana Bank Syariah. Yogyakarta: Jalasutra.

Mukti, Nur Abidah. (2016). Pengaruh BOPO dan FDR Terhadap Profitabilitas BPR Syariah dengan Risiko Pembiayaan Sebagai Variabel Intervening (Studi Empiris Pada Bank Pembiayaan Rakyat Syariah Provinsi DKI Jakarta, Jawa Barat dan Banten yang terdaftar di Bank Indonesia Periode 2012-2015). (Skripsi S1), Fakultas Ekonomi dan Bisnis Universitas Jember

Purbaningsih, Y. P. (2014). The Effect of Liquidity Risk and Non Performing Financing (NPF) Ratio to Commercial Sharia Bank Profitability in Indonesia. International Proceedings of Economics Development and Research(Online), Vol. 73, 12.

Republik Indonesia. Undang-Undang Nomor 21 Tahun 2008 Tentang Perbankan Syariah. 2008, (Online), (www.ojk.go.id, diakses 22 Maret 2017)

- Statistik Perbankan Syariah, Januari 2011-Desember 2016. 20112016, (Online), (www.ojk.go.id, diakses 22 Maret 2017

$\begin{array}{rr}\text { Perbankan dan } & \text { Pentang } \\ \text { Pemerintah Nomor } 72 \text { Tahun } 1992 .\end{array}$


Maulana, et al/Jurnal Ekonomi Syariah Teori dan Terapan Vol. 6 No. 1 Januari 2019: 23-35; PENGARUH FDR TERHADAP ROA DENGAN VARIABEL INTERVENING NPF PADA BPRS INDONESIA

19992, (Online), (www.ojk.go.id,

diakses 22 Maret 2017)

Sabir, dkk. (2012). Pengaruh Rasio Kesehatan Bank Terhadap Kinerja Kevangan Bank Umum Syariah dan Bank Konvensional di Indonesia. Jurnal Analisis, Vol. 1 (No. 1).

Sukarno, \& Syaichu. (2006). Analisis FaktorFaktor yang Mempengaruhi Kinerja Bank Umum di Indonesia. Jurnal
Studi Manajemen \& Organisasi UNDIP, Vol. 3(Nomor 2).

Wibowo. (2013). Analisis Pengaruh Suku Bunga, Inflasi, CAR, BOPO, NPF, Terhadap Profitabilitas Bank Syariah. Jurnal Manajemen UNDIP, Vol. 2 (No.

2). 